\title{
Weed Interference Periods and Transplanting Densities of Onion Crop in the BRazilian Region of Guarapuava, PR ${ }^{1}$
}

\author{
Períodos de Interferência de Plantas Daninhas e Densidades de Transplantio da Cultura da \\ Cebola na Região de Guarapuava, PR
}

\author{
SOUZA, J.I. ${ }^{2}$, SILVA, A.A.P. ${ }^{2}$, CHAGAS, R.R. ${ }^{3}$, OLIVEIRA NETO, A.M. ${ }^{4}$, MACIEL, C.D.G. ${ }^{2}$, \\ RESENDE, J.T.V. ${ }^{2}$, and ONO, E.O. ${ }^{5}$
}

\begin{abstract}
The study was conducted with the objective of determining the critical periods of interference prevention (CPIP) and the best period for the management of weeds community in onion crop Crioula Mercosul genotype, transplanted in distinct plants densities. The experiment was carried out in field conditions in the Brazilian municipality of Guarapuava, Paraná State, during the 2012 and 2013 agricultural years, at Universidade Estadual do Centro-Oeste - UNICENTRO. Treatments were disposed in randomized complete blocks and experimental design, with five repetitions, consisting of weeds coexistence periods and weeds control at 14, 28, 56, 112 and 168 days after transplanting the seedlings (DATS), using 0.6, 0.8 and 1.0 million plants ha ${ }^{-1}$. Weeds community was evaluated through a phytosociological survey at the end of each coexistence period in relation to yield and commercial quality of bulbs. Bulbs yield of transplanted onion was significantly affected by weeds coexistence, reaching $100 \%$ of losses. From adjusted models, viability was not observed in increasing plantation density as a practice that may favor the necessary reduction of weeds control. Onion plants transplanted in August 2012 and July 2013 presented CPIP, respectively, of 23 at 76 and 21 at 120 DATS for commercial bulbs yield, and of 20 at 55 and 26 at 112 DATS for total bulbs yield, respectively.
\end{abstract}

Keywords: Allium cepa, competition, plant arrangement, bulb yield.

RESUMO - O trabalho foi realizado com o objetivo de determinar os periodos criticos de prevenção da interferência das plantas daninhas (PCPI) na cultura da cebola cultivar Crioula Mercosul, transplantada em diferentes densidades. O experimento foi conduzido em campo no municipio de Guarapuava, PR, durante as safras de 2012 e 2013, na Universidade Estadual do Centro-Oeste - UNICENTRO. Os tratamentos obedeceram ao delineamento experimental de blocos ao acaso com cinco repetições, constituidos por periodos de convivência e controle das plantas daninhas aos 14, 28, 56, 112 e 168 dias após o transplantio das mudas (DATM), utilizando 0,6, 0,80 e 1,0 milhão de plantas ha ${ }^{-1}$. A comunidade infestante foi avaliada por meio do levantamento fitossociológico ao final de cada periodo de convivência, em relação à produtividade e qualidade comercial dos bulbos. A produtividade de bulbos de cebola transplantada foi significativamente alterada pela convivência com infestação das plantas daninhas, chegando a $100 \%$ de perdas. A partir dos modelos ajustados, não foi constatada viabilidade no aumento da densidade de plantio como prática que favoreça a redução do periodo necessário para o controle de

Recebido para publicação em 5.10.2015 e aprovado em 31.1.2016.

Universidade Estadual do Centro-Oeste, PPGA/UNICENTRO. Guarapuava-PR, Brasil, <jigor.souza@ymail.com>; ${ }^{3}$ Universidade Federal de Lavras, UFLA. Lavras-MG, Brasil; ${ }^{4}$ Universidade Federal de Pelotas, UFPEL, Pelotas-RS, Brasil; ${ }^{5}$ Universidade Estadual Paulista Júlio de Mesquita Filho, UNESP, Botucatu-SP, Brasil.

Planta Daninha, Viçosa-MG, v. 34, n. 2, p. 299-308, 2016 
plantas daninhas. A cebola transplantada em agosto de 2012 e julho de 2013 apresentou PCPI, respectivamente, de 23 aos 76 e 21 aos 120 DATM para a produtividade de bulbos comerciais, e de 20 aos 55 e 26 aos 112 DATM, para a produtividade de bulbos totais, respectivamente.

Palavras-chave: Allium cepa, competição, arranjo de plantas, produção de bulbos.

\section{INTRODUCTION}

Onion crops (Allium cepa), just like any other crop, are subjected to the effects of biotic and abiotic factors that influence their yield. One of the main biotic factors that negatively interfere in onion yield is the presence of weeds (Soares et al., 2003); the lack of control or inadequate control of such vegetation intensify the problem of weed interference in crops (Usman et al., 2005).

Low competition capacity of onion crops with the infesting weed community is reported and emphasized when referring to the early crop development stages (Garcia et al., 1994; Soares et al., 2003; Qasem, 2005). Therefore, crops should be kept free from weed interference for a certain period so that there is no yield reduction. Losses caused by the coexistence with the weeds can be severe, and the reduced bulbs yield can increase according to the competition period and the weeds. According to Zanatta et al. (2006), long periods of competition of the weed community with the crop can reduce the bulbs yield at $100 \%$, compared to the condition without its interference.

Weeds interference in vegetable crops intensifies because of the cultivation areas going through intensive exploitation, frequent tillage, high fertilization rates and low water restriction (Pitelli, 1985). Therefore, this environment is favorable to the occurrence of weeds, which are fast-growing, have a short development cycle and high production of diaspores, significantly increasing the soil seed bank (Carvalho et al., 2008).

The competition of weeds with crops occurs by the limited resources from the environment, such as light, nutrients, water and space (Pitelli, 1985). The result of this competition depends on factors related to the culture (species, cultivar and plant population), the weed community (specific composition, density and distribution), the management adopted (both for culture and for weeds) and the period of coexistence between the culture and the weed community (season and duration), and all these factors are influenced by climate and soil conditions of the environment.

As the season and duration of the coexistence period are the main factors influencing the interference relationship between the weed community and the culture, in weed interference studies the possibility of the occurrence of three periods is considered: a) period before interference (PBI), in which after emergence weeds can coexist with the culture without causing economic losses; b) total period of interference prevention (TRIP), wherein the control practices start with the emergence of weeds and crop and their end reflects the time at which the culture is capable of preventing weeds interference; and c) critical period of interference prevention (CPIP), which refers to the final period of the PBI to the TPIP, wherein the presence of weeds must be prevented by performing control practices. Thus, knowledge of these periods is essential to establish management strategies of weeds and is characterized as key to achieving high yield in potherbs (Zanatta et al., 2006).

Soares et al. (2004) have mentioned that there is a wide variation in the results of weed interference studies available in the literature; for onion transplanted, these periods range between 7 and 60 days for PBI and between 7 and 80 days for TPIP. Recently, Cavalieri (2013) has reported that search results on weed interference on onion crops indicate, on average, the critical periods of interference prevention (CPIP) as being from the $21^{\text {th }}$ to the $63^{\text {th }}$ days and from the $27^{\text {th }}$ to 
the $56^{\text {th }}$ days of the cycle for the direct seeding systems and seedlings transplant, respectively.

Moreover, among the phytotechnical management aspects that are key for commercial production of bulbs, which is directly related to weed interference, the establishment of the ideal plant population per hectare, the cultivar and the cultivation system are highlighted (Baier et al., 2009; Menezes Júnior \& Vieira Neto, 2012).

Given the above, onion crop yield and quality may be influenced by weeds coexisting with the culture in different periods during the development cycle, as well as some cultivation control practices, such as the proper arrangement of the plant population. Thus, the aim of this study was to estimate the periods of coexistence and weed control in onion crops transplanted in the Brazilian region of Guarapuava, PR, using three population densities during two agricultural years.

\section{MATERIALS AND METHODS}

The study was divided in two experiments carried out in the field in the periods from August to December 2012 (harvest 1) and from July to January 2013/2014 (harvest 2), located in the Olericulture Sector belonging to the Agronomy Department at Central-West State University (UNICENTRO - Universidade Estadual do Centro-Oeste), Campus CEDETEG/ UNICENTRO, under coordinates $23^{\circ} 12$ ' $28,8^{\prime \prime} \mathrm{S}$ latitude, $53^{\circ} 18^{\prime} 14,7$ " W longitude and 1,020 m altitude. The area climate is classified as $\mathrm{Cfb}$ humid subtropical mesothermal (Köppen, 1948), with cool summers, winters with the occurrence of severe and frequent frosts, and no significant dry season. The soil of the experimental area is classified as typical alic bruno latosol (Embrapa, 2013) clayey textured (50\% clay, $20 \%$ sand and $30 \%$ silt), which, in a chemical analysis of samples from 0 to $\ldots \mathrm{cm}$ deep showed $\mathrm{pH}\left(\mathrm{CaCl}_{2}\right)$ of $5.7 ; \mathrm{OM}$ of $28.2 \mathrm{~g} \mathrm{dm}^{-3}$; $\mathrm{P}$ of $11.1 \mathrm{mg} \mathrm{dm}^{3}$; and 0.29, 6.4, 2.6, 0.0 per $\mathrm{cmol}_{\mathrm{c}} \mathrm{dm}^{-3}$ of $\mathrm{K}, \mathrm{Ca}, \mathrm{Mg}$ and $\mathrm{Al}$, respectively.

The seedlings were obtained in beds used as "seedbeds" and onion sowing was done by sowing about 60 days before the final transplanting, using $10 \mathrm{~g}$ of seed $\mathrm{m}^{-2}$ of cultivar Crioula Mercosul, in a bed raised with the use of a rotary seedbed maker. The transplantation was performed when the seedlings were in the stage of two to three leaves, or about $15 \mathrm{~cm}$ high, while keeping the spacing at $0.15 \mathrm{~cm}$ and ranging the spacing between plants in $0.065,0.08$ and $0.10 \mathrm{~m}$, which respectively constituted the population densities of $0.6,0.8$ and 1.0 million plants ha ${ }^{-1}$. Harvests 1 and 2 were manually transplanted on 08/29/2012 and 07/27/2013, respectively.

One day before transplanting the seedlings, basic fertilization was done with the formula N-P-K (03-16-08), using 312 and $475 \mathrm{~kg} \mathrm{ha}^{-1}$, respectively, for harvests 1 and 2 . At 15 and 35 days after transplanting, side dressings were carried out with the mix of urea and potassium chloride in the amounts of 450 and $75 \mathrm{~kg} \mathrm{ha}^{-1}$, respectively. Irrigation was performed weekly with a micro-sprinkler system, according to the crop needs. To control pests and diseases, insecticides and fungicides applications were made using products registered for the crop in the Brazilian state of Paraná, in their recommended doses.

The experiment was conducted in an experimental design of randomized blocks in a $10 \times 3$ factorial arrangement with five repetitions. In both harvests, ten treatments consisted of five periods of coexistence and five of absence of coexistence of the onion crop with the weed community during the time interval of 14, 28, 56, 112 and 168 days after transplanting the seedlings (DATS) in three densities of plants $(0.6,0.8$ and 1.0 million of plants ha ${ }^{-1}$ ). In the 2012 harvest, due to the seedlings having been transplanted later, the crop reached full circle at 112 DATS, being harvested in November 2012. At this stage, weed control in crop inter-rows and rows was done by hand weeding, considering the schedule and the need for treatments. Each experimental unit consisted of plots of five planting rows measuring $1.5 \mathrm{~m}$ long by $0.8 \mathrm{~m}$ wide and floor area measuring $1.2 \mathrm{~m}^{2}$, since $0.1 \mathrm{~m}$ of the ends and the external rows were considered only as a border.

At the end of each coexistence period, weeds density identification and determination were done, as well as weeds shoots dry matter 
quantification (WSDM) using technical criteria adopted in phytosociological surveys, according to concepts described by Concenço et al. (2013). This procedure was carried out using a $0.25 \mathrm{~m}^{2}$ area square-shaped metallic jig and random sowing per plot was done. Weeds shoots were collected and separated into monocotyledons and eudicotyledons. Samples were dried in an air forced circulation stove at $60{ }^{\circ} \mathrm{C}$ until constant weight, and then weighed on a precision scale. The classification system adopted in species identification was based on the Angiosperm Phylogeny Group - APG II (2003) with the help of the boundaries of families and arrangement of some genera, according to Souza \& Lorenzi (2005), and other literature (Kissman \& Groth, 1997, 1999, 2000; Lorenzi, 2006, 2008).

The harvesting point was determined by drying the lower leaves and "popping" of about $80 \%$ of the plants, according to the methodology described by Baier et al. (2009). After harvesting, the onion bulbs were kept in a shed for the "curing" process, where they were subjected to the cleaning process, weighing and percentage sorting, according to the cross-sectional diameter (CEAGESP, 2001a, b), in class 5 (diameter higher than $9 \mathrm{~cm}$ ), class 4 (diameter between 7 and $9 \mathrm{~cm}$ ), class 3 (diameter between 7 and $5 \mathrm{~cm}$ ), class 2 (diameter between 5 and $3.5 \mathrm{~cm}$ ) and scrap (diameter lower than $3.5 \mathrm{~cm}$ ) with a precision scale and a classifier built for this purpose.

Yield results of marketable bulbs $\left(\mathrm{kg} \mathrm{ha}^{-1}\right)$, considering only the sum of classes 3 to 5 , and the total bulb yield $\left(\mathrm{kg} \mathrm{ha}^{-1}\right)$, determined considering $8,000 \mathrm{~m}^{-2}$ of floor area, were subjected to analysis of variance by the F-test $(\mathrm{p}<0.01$ and 0.05$)$ and regression analysis using the statistical software SigmaPlot $11.0^{\circledR}$. Determining the periods before interference (PBI), total period of interference prevention (TPIP) and critical period of interference prevention (CPIP) was carried out by estimating losses of $5 \%$ compared to the treatment that was developed free of coexistence with weeds, considering that this value refers to the chemical control cost.

For trend analysis of the effects of interference periods on the yield of marketable bulbs and total bulbs of onion crops, regression studies were carried out. Mathematical models adjusted were Logistic and Gompertz, respectively, to estimate PBI (1) and TPIP (2), as described by Knezevic et al. (2002). Those models were the ones that best explained the biological behavior of the phenomenon evaluated, considering the significance of the parameters, the mean squares of the waste and the values of $\mathrm{R}^{2}$ (Alvarez V. \& Alvarez, 2006).

$$
\begin{aligned}
& Y=A /(1+A B S(D A T M / K) * \operatorname{EXP}(B)) \\
& Y=A^{*} \operatorname{EXP}(-E X P(-(D A T M-K) / B))
\end{aligned}
$$

where $Y$ refers to the yield of commercial or total bulbs, expressed in $\mathrm{kg} \mathrm{ha}^{-1}$; $A$ refers to the maximum asymptote in $\mathrm{kg} \mathrm{ha}^{-1}$; DATM refers to days after transplanting seedlings in which the crop remained free or subject to coexistence with weed infestation; and $B$ and $K$ are constants of the model.

\section{RESULTS AND DISCUSSION}

Weeds identified in the experimental area formed by the culture of onion transplanted in harvests 2012 and 2013 in the Brazilian municipality of Guarapuava, PR, totaled 24 and 20 species, distributed in 13 and 10 families, respectively. Families Asteraceae, Poaceae and Euphorbiaceae were those that showed the highest number of species in the two harvests studied, even with such contrasting weather conditions, according to variations in temperature and precipitation distribution (Figure 1).

In general, the main species that occurred during the experiment were Digitaria horizontalis, Raphanus raphanistrum, Brachiaria plantaginea, Amaranthus sp. and Richardia brasiliensis, in the 2012 harvest, and $R$. raphanistrum, D. horizontalis, Ambrosia artemiifolia, B. plantaginea and Bidens subalternans, in the 2013 harvest. However, with respect to the shoots total dry matter of weeds recorded in harvests 2012 and 2013 (Figure 3), a progressive increase took place. The highest total yields were obtained by all the eudicotyledons species, and at all times of the evaluation they were always higher than those of the monocotyledons (Figures 2A, B). 


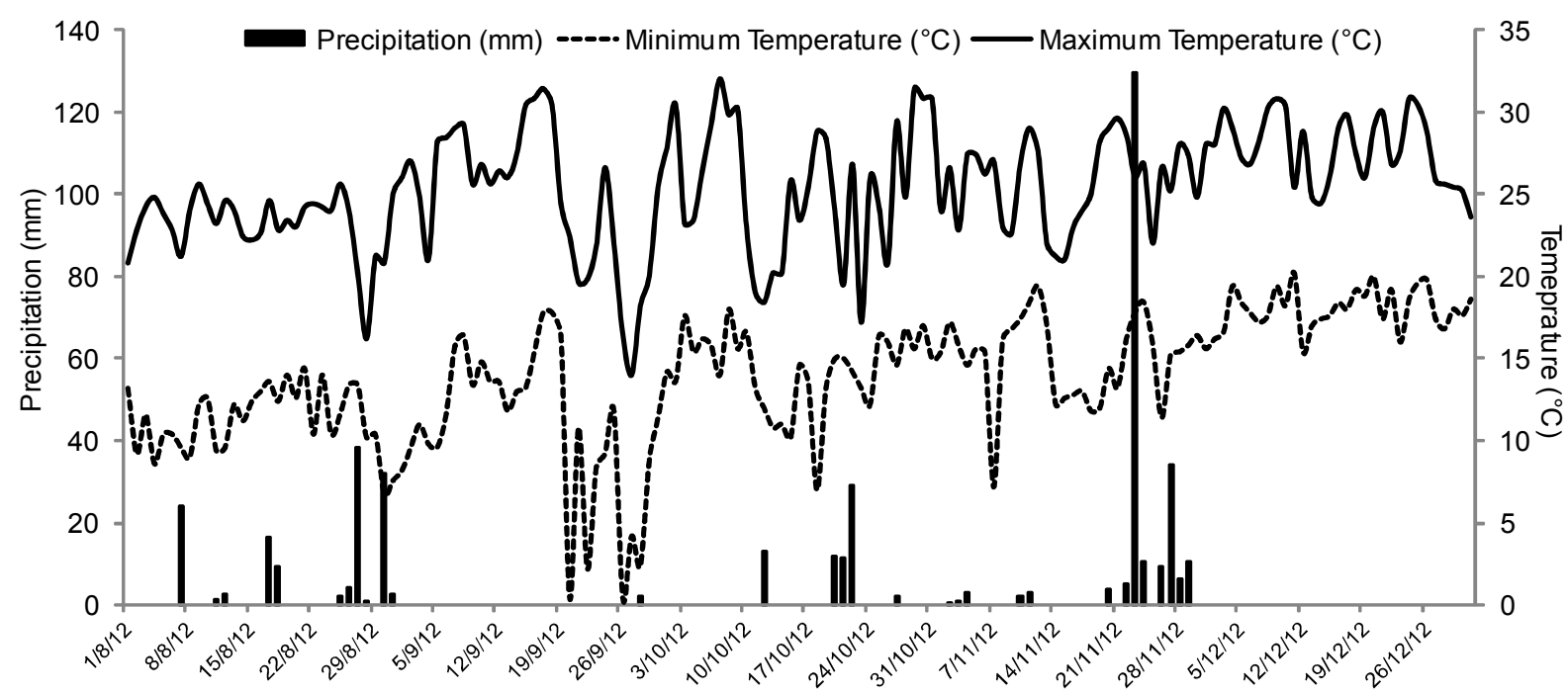

Day/mouth/year (Harvest 2012)

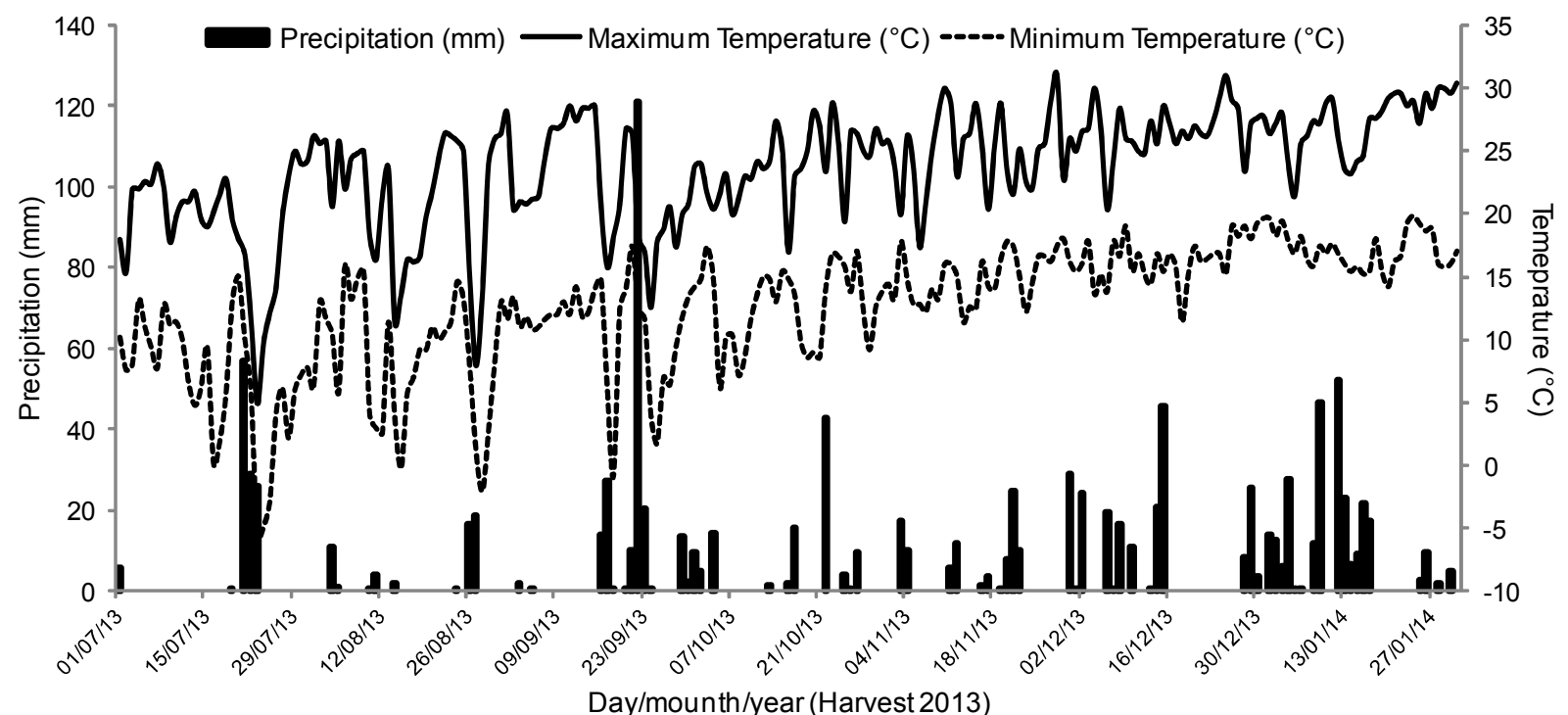

Figure 1 - Precipitation $(\mathrm{mm})$ and maximum and minimum temperatures $\left({ }^{\circ} \mathrm{C}\right)$ during the development of onion crop transplanted in the 2012 and 2013 harvests. Guarapuava, PR, 2012/2013.

Despite the great similarity of weed species that occurred between harvests on both infested conditions, they showed great competitive ability, especially in the 2012 harvest, since the dry mass of shoots tended to increase even with the reduction of their population (Figures 2A, B). According to Radosevich et al. (1997), as the population increases and the weeds grow, especially at the beginning of the cycle, the interspecific and intraspecific competition processes intensify, with domain and suppression of weeds of greater stature on the smaller ones.
This description explains the reduction in the weeds density in crops evaluated by increasing the shoots dry matter during the crop cycle (Afifi \& Swanton, 2011). For Meschede et al. (2004), the accumulated dry matter is more important than the weeds density and shows an inverse correlation to the yield components of the crop.

The experimental units in which the onion crop was kept for increasing initial periods in coexistence with the weeds allowed to calculate the period in which these can 
emerge and infest the crop without losses in yield. In this sense, it was verified that in 2012 and 2103 harvests 25 and 21, 21 and 25, 23 and 17 DATS were necessary for the onion crop harvested in densities of 0.6, 0.8 and 1.0 million plants ha ${ }^{-1}$, respectively, to show significant yield losses of commercial bulbs (Figures 3 and 4). This period corresponds to the period before interference (PBI); weed control should be effectively carried out before that time so that there are no yield losses. As for the total period of interference prevention (TPIP) in the 2012 and 2103 harvests, total control of infestation was necessary up to 67 and 106, 70 and 120, 83 and 134 DATS for the onion crop, harvested in densities of $0.6,0.8$ and 1,0 million plants ha ${ }^{-1}$, respectively, to be able to stand out in relation to weeds, not showing significant losses of commercial bulbs (Figures 3 and 4).

When analyzing the yield of total bulbs, it was observed that there was a great similarity of the responses to those identified for commercial bulbs in the 2012 and 2013 harvests, specially for the PBI values (Figures 3
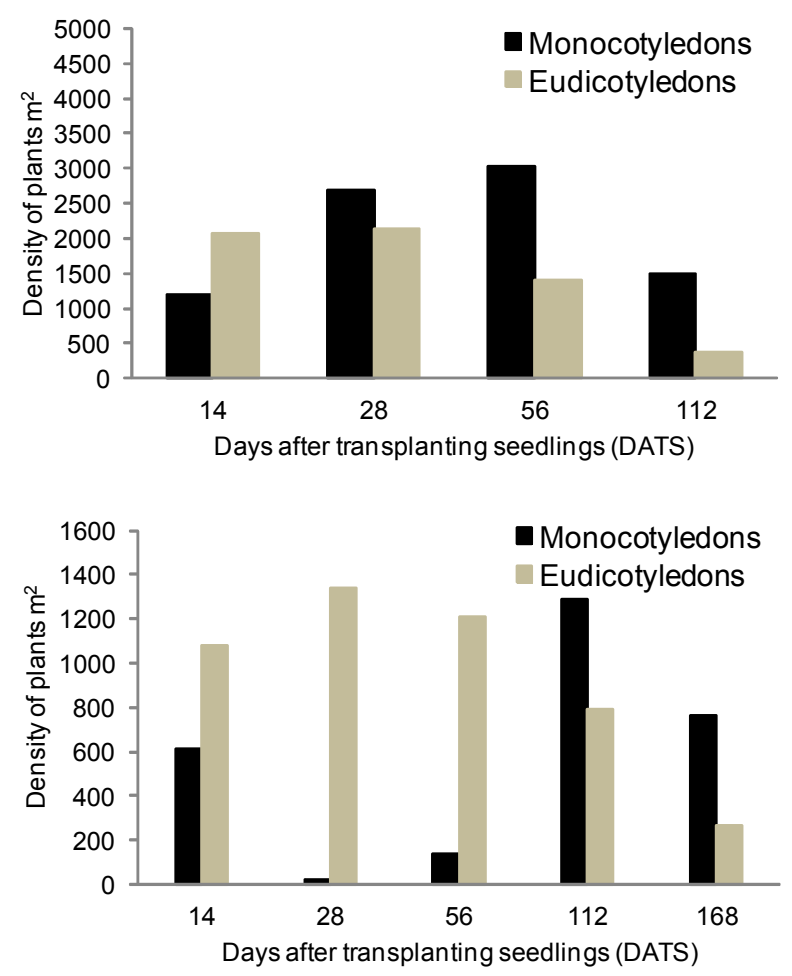

and 4). However, in both cases there was no evidence of a behavior trend that could justify the increase and/or reduction in planting density to favor weeds control in the onion crop transplanted in Guarapuava, PR. In both crops, increased population density of the onion transplanted provided yield drop of commercial bulbs, regardless of coexistence or not with weeds. These results corroborated those reported by Viegas D'Abreu (1996), Stoffella (1996), Rumpel \& Felczynski (2000), Cecílio Filho et al. (2006) and Resende \& Costa (2006), who found a greater reduction in bulbs yield with the increase of the crop planting density. However, Baier et al. (2009) have found that increasing the density of onion plants per $\mathrm{m}^{2}$ gave lower average mass of bulbs and increased yield in commercial classification 3 filled in a study conducted in Guarapuava, PR.

Thus, for the commercial bulbs yield, considering the average of the results among the planting densities studied, the period in which the control practices must be effectively adopted (CPIP) was characterized by the period between 23 at 73 and 21 at 120 DATS,
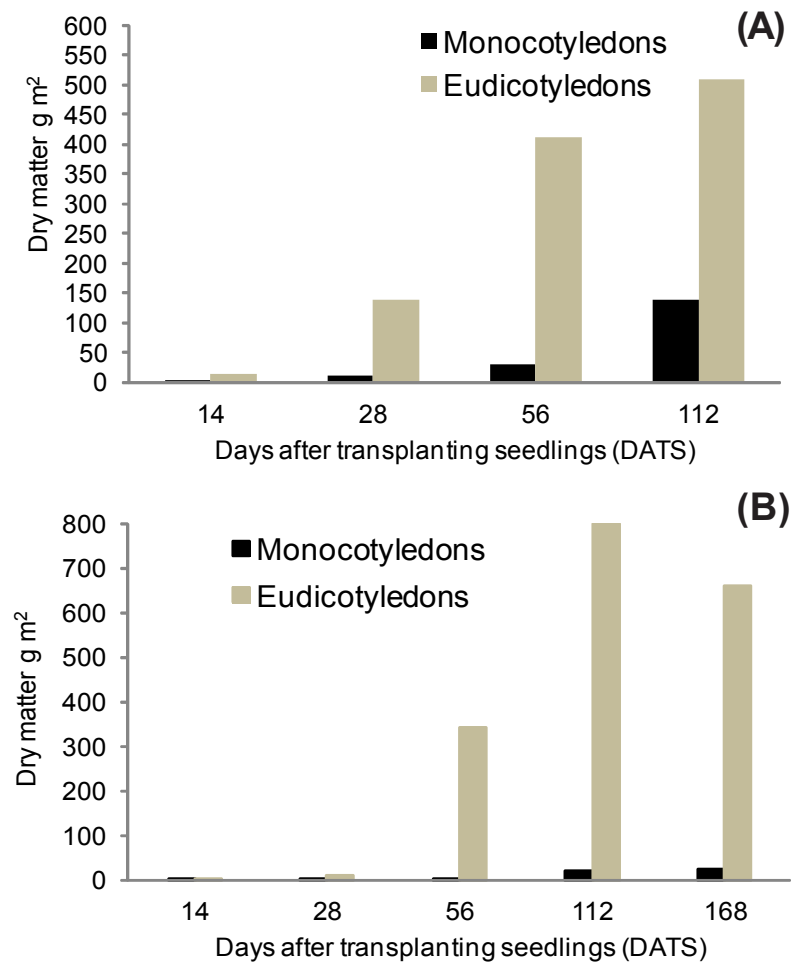

Figure 2 - Weed density (plants $\left.\mathrm{m}^{-2}\right)$ and dry matter $\left(\mathrm{g} \mathrm{m}^{-2}\right)$ after different periods of coexistence with onion crop transplanted in the 2012 (A) and 2013 (B) harvests. Guarapuava, PR, 2012/2013. 

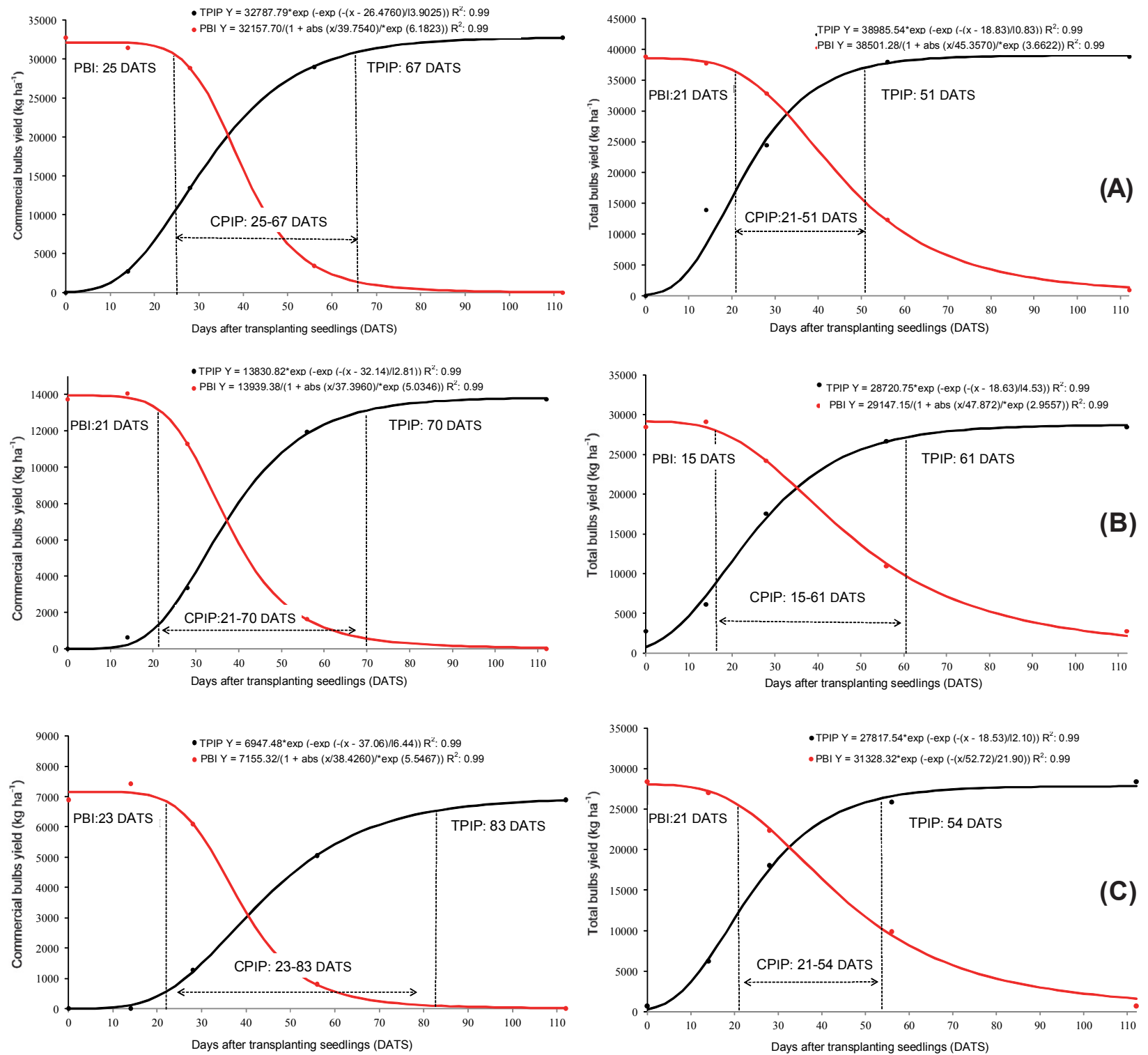

Figure 3 - Commercial bulbs yield and totals of onion transplanted in densities of 0.6, 0.8 and 1.0 million plants ha-1 (A, B and C) subjected to coexistence periods (PBI) and control (TPIP) of weeds in the 2012 harvest. Guarapuava, PR, 2012.

respectively, for the 2012 and 2013 harvests. As for the total bulbs yield, the average of results among planting densities, CPIP was characterized as of 20 at 55 and 26 at 112 DATS, respectively, for the 2012 and 2013 harvests.

Importantly, in the 2012 harvest planting was done too late, resulting in anticipation of the growing season and harvest at 112 DATS, and in the 2013 harvest there was frost, resulting in delays in the development of weeds. In this sense, due to the weeds shoots dry matter formation (Figure 2) and/or covering of the soil surface in the experimental units, earliest development of the weed community was found in the 2012 harvest and later in the 2013 harvest. These results partially corroborate those by Cavalieri (2013), who mentions that the critical periods of weeds interference prevention (CPIP) in the onion culture transplanted, on average, will be from the $27^{\text {th }}$ to the $56^{\text {th }}$ days of the crop cycle; those by Garcia et al. (1994), in a study developed in 

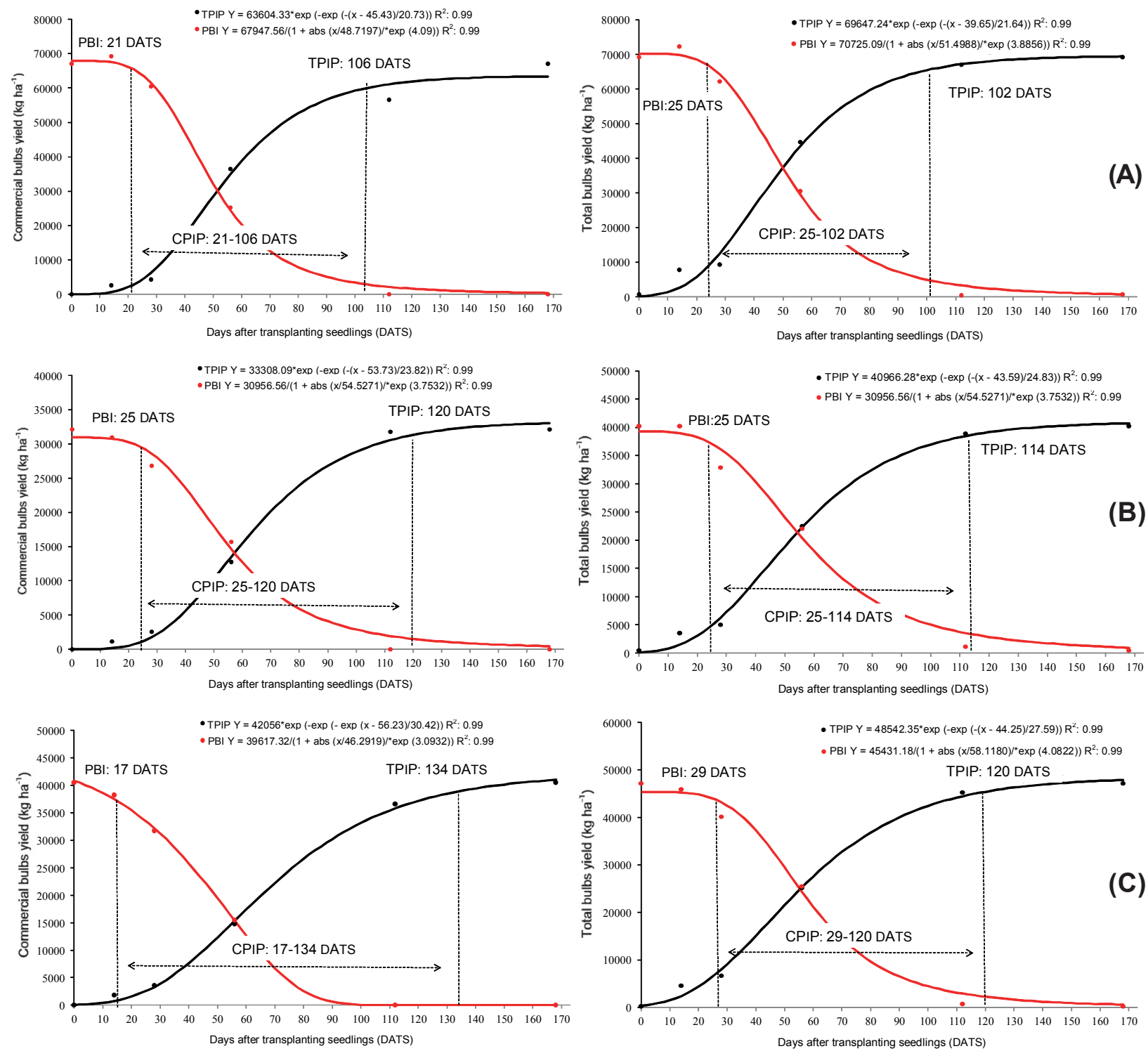

Figure 4 - Commercial bulbs yield and totals of onion transplanted in densities of 0.6, 0.8 and 1.0 million plants ha ${ }^{-1}(\mathrm{~A}, \mathrm{~B}$ and $\mathrm{C})$ subjected to coexistence periods (PBI) and control (TPIP) of weeds in the 2013 harvest. Guarapuava, PR, 2013.

the Brazilian State of Rio Grande do Sul, who reported TPIP of three onion cultivars as being from 61 to 74 DATS; and those by Paller et al. (1971) and Bond \& Burston (1996), who reported values of TPIP for the onion transplanted as being from 49 to 56 and 21 to 56 DATS, respectively.

This variation in results is due to the action of factors that influence the degree of interference of the weed community on the crop, such as the set of prevailing weeds and the cultivars used. Conversely, in a study developed in the Brazilian region of Jaboticabal, SP, Soares et al. (2003) have reported the occurrence of PBI of 42 DATS for onion cultivars Mercedes, Granex33, Superex and Serrana. Therefore, the regional knowledge of interference periods may feature more or less need for infestation control for transplanted onion, or even the establishment of more appropriate dosages of the herbicides, which therefore will allow the reduction of the amount and frequency of the control interventions, the production cost and possible environmental impact. 
In view of the results, it can be concluded that onion Crioula Mercosul transplanted in the Brazilian region of Guarapuava, PR, showed, on average, CPIP of 23 at 73 and 21 at 120 DATS for the commercial bulbs yield. No viability in increasing plant density in the transplanting was found as a management practice that favors the reduction of CPIP without impairing the yield of commercial and/or total bulbs of the crop.

\section{ACKNOWLEDGEMENT}

The authors are grateful to Capes/ Fundação Araucária (Coordenação de Aperfeiçoamento de Pessoal de Nivel Superior/ Fundação Araucária) for granting the scholarship.

\section{LITERATURE CITED}

AFIFI, M.; SWANTON, C. J. Maize seed and stem roots differ in response to neighbouring weeds. Weed Res., v. 51, n. 5, p. 442-450, 2011.

ALVAREZ, V. H.; ALVAREZ, G. A. M. Comparações de médias ou testes de hipóteses? Contrastes! B. Inf. SBCS, v. 31, n. 1, p. 24-34, 2006.

ANGIOSPERM PHYLOGENY GROUP - APG II. An update of the Angiosperm Phylogeny Group classification for the orders and families of flowering plants: APG II. Bot. J. Linnean Soc., n. 141, p. 399-436, 2003.

BAIER, J. E. et al. Produtividade e rendimento comercial de bulbos de cebola em função da densidade de cultivo. Ci. Agrotecnol., v. 33, n. 2, p. 496-501, 2009.

BOND, W.; BURSTON, S. Timing the removal of weeds from drilled salad onions to prevent crop losses. Crop Protec., v. 15, n. 2, p. 205-211, 1996.

CARVALHO, L. B. et al. Interferência e estudo fitossociológico da comunidade infestante na cultura da beterraba transplantada. Acta Sci. Agron., v. 30, n. 3, p. 325-331, 2008.

CAVALIERI, S.D. Árvore do conhecimento cebola: Plantas daninhas - matointerferência. Agência Embrapa de Informação tecnológica. AGEITEC, 2013. Disponível em: <http:// www.agencia.cnptia.embrapa.br/gestor/cebola/arvore/ CONT000gn9eurvp02wx5ok0liq1mqz0umhli.html>. Acesso em: 12 mar. 2014.

COMPANHIA DE ENTREPOSTOS E ARMAZÉNS GERAIS DO ESTADO DE SÃO PAULO - CEAGESP. Programa Brasileiro para a melhoria dos padrões comerciais e embalagens de hortigranjeiros. São Paulo: 2001a.
COMPANHIA DE ENTREPOSTOS E ARMAZÉNS GERAIS DO ESTADO DE SÃO PAULO - CEAGESP. Programa brasileiro para modernização da horticultura: Classificação da cebola (Allium cepa L.). Impresso CEAGESP, 2001b. Disponível em: <http://www.ceagesp.gov.br/wpcontent/uploads/2015/07/cebola.pdf $>$. Acesso em: 12 jul. 2015 .

CECÍLIO FILHO, A. B. et al. produtividade e qualidade de bulbos de duas cultivares de cebola em função da população de plantas, em semeadura direta. Caatinga, v. 19, n. 2, p. 146-152, 2006.

CONCENÇO, G. et al. Phytosociological surveys: tools for weed science. Planta Daninha, v. 31, n. 2, p. 469-482, 2013.

EMPRESA BRASILEIRA DE PESQUISA AGROPECUÁRIA - EMBRAPA. Sistema brasileiro de classificação de solos. 3.ed. Brasília, DF: 2013. 353 p.

GARCIA, D. C.; BARNI, V.; STORCK. L. Influência da interferência de plantas daninhas no rendimento de bulbos de cebola. Pesq. Agropec. Bras., v. 29, n. 10, p. 1557-1563, 1994.

KISSMANN, K. G.; GROTH, D. Plantas infestantes e nocivas. 2.ed. São Paulo: BASF, 1997. Tomo I. 825 p.

KISSMANN, K. G.; GROTH, D. Plantas infestantes e nocivas. 2.ed. São Paulo: BASF, 1999. Tomo II. 978 p.

KISSMANN, K. G.; GROTH, D. Plantas infestantes e nocivas. 2.ed. São Paulo: BASF, 2000. Tomo III. 722 p.

KNEZEVIC, S. Z. et al. Critical period for weed control: the concept and data analysis. Weed Sci., v. 50, n. 6, p. 773-786, 2002.

KÖPPEN, W. Climatologia: com um estudio de los climas de la tierra. México: Fondo de Cultura Econômica, 1948. $478 \mathrm{p}$.

LORENZI, H. Manual de identificação e controle de plantas daninhas: plantio direto e convencional. 6.ed. Nova Odessa: Plantarum, 2006. 339 p.

LORENZI, H. Plantas daninhas do Brasil: terrestres, aquáticas, parasitas e tóxicas. 4.ed. Nova Odessa: Plantarum, 2008. 640 p.

MESCHEDE, D. K. et al. Período anterior à interferência de plantas daninhas em soja: estudo de caso com baixo estande e testemunhas duplas. Planta Daninha, v. 22, n. 2, p. 239-246, 2004.

MENEZES JÚNIOR, F. O. G.; VIEIRA NETO, J. Produção da cebola em função da densidade de plantas. Hortic. Bras., v. 30, n. 4, p. 733-739, 2012. 
PALLER, E. C. Jr. et al. Duration of weed competition and control and yield. II. Transplanted onions. Philippine Agric. v. 55, n. 516, p. 221-224, 1971.

PITELLI, R. A. Interferência de plantas daninhas em culturas agrícolas. Inf. Agropec., v. 11, n. 129, p. 16-27, 1985.

QASEM, J. R. Critical Period of Weed Competition in Onion (Allium cepa L.) in Jordan. Jordan J. Agric. Sci., v. 1, n. 1, p. 32-42, 2005.

RADOSEVICH, S. R.; HOLT, J.; GHERSA, C. Ecology of weeds and invasive plants: relationship to agriculture and natural resource management. 3.ed. New York: John Wiley and Sons, 2007. 454p.

RESENDE, G. M.; COSTA, N. D. Produtividade e massa fresca de bulbos de cebola sob densidades de plantio no Vale do São Francisco. Hortic. Bras., v. 24, n. 2, p. 228-232, 2006.

RUMPEL, J.; FELCZYNSKI, K. Effect of plant density on yield and bulb size of direct sown onions. Acta Hortic., v. 533 , n. 1 , p. 179-186, 2000.
SOARES, D. J. et al. Períodos de interferência das plantas daninhas na cultura de cebola (Allium cepa) transplantada. Planta Daninha, v. 21, n. 3, p. 387-396, 2003.

SOARES, D. J. Importância das plantas daninhas na cultura da cebola. J. ConsHerb, v. 2, n. 7, p. 2-3, 2004.

SOUZA, V. C.; LORENZI, H. Botânica sistemática: guia ilustrado para identificação das famílias de angiospermas da flora brasileira, baseado em APG II. Nova Odessa: Plantarum, 2005. $640 \mathrm{p}$.

STOFFELLA, P. J. Planting arrangement and density of transplants influence sweet Spanish onion yields and bulb size. HortScience, v. 31, n. 7, p. 1129-1130, 1996.

USMAN, K. et al. Integrated weed management in okra. Pakistan J. Weed Sci. Res., v. 11, n. 1-2, p. 55-60, 2005.

VIEGAS D'ABREU, D. A. Effect of nitrogen and spacing on bulb splitting in onion cv. Bombay Red. TVIS Newsletter, v. 1, n. 2, p. 1-26, 1996.

ZANATTA, J. F. et al. Interferência de plantas daninhas em culturas olerícolas. R. FZVA, v. 13, n. 2, p. 39-57, 2006. 